Jurnal Penelitian dan Karya Ilmiah

\title{
PENINGKATAN KEMAMPUAN REPRESENTASI MATEMATIS SISWA \\ KELAS IX-G SMP NEGERI 2 BANDUNG PADA MATERI PERSAMAAN KUADRAT DENGAN DISCOVERY LEARNING MODEL
}

\author{
${ }^{1}$ Siti Tuti Alawiyah, \& ${ }^{2}$ Jarnawi Afgani Dahlan \\ 1, 2 Program Studi Pendidikan Matematika FPMIPA UPI \\ Email: tutialawiyah2193@gmail.com
}

\begin{abstract}
Representative ability is the ability to express mathematical ideas that are used to show the results of his work in certain ways as a result of the interpretation of his mind. Based on the results of observations obtained data that the class on IX-G SMP 2 Bandung experienced a difficulty in presenting mathematical ideas. Difficulties experienced by students of class IX$G$ are a problem that must be addressed immediately because of how students can express mathematical ideas if students cannot develop representations properly. After the initial test, it turns out that the representation ability of students in class IX-G is in the low category. Based on the background of the problem found, the researcher carried out classroom action research to overcome the problems experienced by class IX-G. The objectives of this study are: (1) Knowing the increase in students' mathematical representation abilities with discovery learning models in class IX-G of SMP Negeri 2 Bandung. (2) Describing the response of students of class IX-G SMP Negeri 2 Bandung to the implementation of learning using discovery learning models. (3) Analyzing the effectiveness of the implementation of mathematics learning by using discovery learning models in improving the ability of mathematical representation. This classroom action research was conducted in 2 cycles. The subjects in this study were class $I X-G$, which amounted to 32 students consisting of 18 men and 14 women. Data collection was done using formative tests of mathematical representation abilities, student response questionnaires, and observation sheets of teacher and student activities. The results of this study as a whole have been successful because they have been able to improve students' representation abilities significantly and student learning outcomes are completed in a classical manner. This can be seen by the increase in the value of classical absorption ability of students' mathematical representation abilities from cycle I to cycle II. The absorption ability of students' mathematical representation in the first cycle was $31.25 \%$, in the second cycle it increased to $87.50 \%$. In addition, students' responses to learning are in good criteria. The effectiveness of implementing mathematics learning by using discovery learning models in improving the ability of mathematical representation is good.
\end{abstract}

Keywords: Communication, Discovery Learning

38 I Pelita - Jurnal Penelitian dan Karya Ilmiah 
Edisi XIX Volume 1, Januari - Juni 2019

Jurnal Penelitian dan Karya Ilmiah

\section{A. PENDAHULUAN}

Pada era globalisasi sekarang ini dunia mengalami persaingan dalam berbagai bidang, salah satunya yaitu bidang pendidikan, sehingga bangsa ini perlu pendidikan yang berkualitas agar tercipta sumber daya manusia yang berkualitas pula. Untuk mencapai pendidikan yang berkualitas itu ditunjang oleh proses pembelajaran yang baik dari berbagai mata pelajaran, salah satunya adalah pembelajaran matematika

Pembelajaran matematika adalah salah satu penunjang atau terciptanya pendidikan yang berkualitas. Pembelajaran matematika sangat erat kaitannya dengan pola pikir manusia yang berpengaruh dalam kehidupan sehari-hari. Dalam dokumen The National Council of Teachers of Mathematics (NCTM, 2000, hlm. 29) menetapkan bahwa terdapat lima kemampuan yang harus dimiliki siswa dalam pembelajaran matematika, yakni: pemecahan masalah matematis (mathematical problem solving), komunikasi matematis (mathematical communication), penalaran matematis (mathematical reasoning), koneksi matematis (mathematical connection), representasi matematis (mathematical representation). Representasi yang dimunculkan oleh siswa merupakan ungkapan dari gagasan-gagasan atau ideide matematis yang ditampilkan siswa dalam upaya mencari solusi dari masalah yang sedang dihadapinya sebagai hasil interpretasi pikirannya (NCTM, 2000, hlm.67).

Berdasarkan tujuan pembelajaran matematika yang tercantum dalam Permendikbud No. 58 tahun 2014 , untuk memahami konsep matematika siswa diharuskan dapat menyajikan konsep dalam bentuk representasi matematis. Representasi adalah bentuk interpretasi pemikiran siswa terhadap suatu masalah yang digunakan sebagai alat bantu untuk menemukan solusi dari suatu masalah. Bentuk interpretasi siswa berupa kata-kata atau verbal, tulisan, gambar, tabel, grafik, benda konkrit, simbol matematika.

Dari uraian tersebut, jelas bahwa kemampuan representasi matematis itu penting. Representasi matematis merupakan suatu hal sering muncul ketika orang mempelajari matematika pada setiap tingkatan pendidikan, maka dipandang representasi merupakan suatu komponen yang layak mendapat perhatian serius. Dengan demikian representasi matematis perlu dicapai dalam proses pembelajaran matematika di sekolah.

Ketercapaian kemampuan representasi dalam pembelajaran matematika di sekolah khususnya di SMP Negeri 2 Bandung belum mencapai hasil yang optimal. Berdasarkan data hasil ulangan harian pada bab perpangkatan, diperoleh data bahwa kemampuan representasi matematis siswa masih rendah dan perlu ditingkatkan.

Salah satu penyebab rendahnya representasi matematis siswa adalah ketidaklancaran prosedur dalam mengerjakan soal, daya ingat siswa yang lemah, siswa cenderung menghafalkan rumus, siswa kurang mengomunikasikan ide matematis, siswa kurang minat dalam menuliskan sesuatu ke dalam bentuk

39 I Pelita - Jurnal Penelitian dan Karya Ilmiah 
PENINGKATAN KEMAMPUAN REPRESENTASI MATEMATIS SISWA

KELAS IX-G SMP NEGERI 2 BANDUNG PADA MATERI

PERSAMAAN KUADRAT DENGAN DISCOVERY LEARNING MODEL

Siti Tuti Alawiyah, \& Jarnawi Afgani Dahlan

geometri, dan siswa cenderung malas menggambarkan situasi. Prihatin (Risnawati, 2012, hlm. 3) dalam penelitiannya menyatakan bahwa:

Kemampuan representasi matematis siswa SMP masih belum tertangani dengan baik dikarenakan keterbatasan pengetahuan guru dan kebiasaan siswa dalam belajar dengan cara konvensional belum memungkinkan bisa menumbuhkan kemampuan representasi secara optimal.

Menyikapi permasalahan yang timbul berdasarkan observasi dan wawancara, peneliti menduga perlu adanya peningkatan kemampuan representasi matematis terhadap materi pembelajaran dengan melakukan inovasi di dalam kelas. Kurikulum 2013 itu ada sebagai penyempurnaan terhadap kurikulum sebelumnya. Hal itu berarti akan ada pengimplementasian strategi pembelajaran yang bagus terhadap pembelajaran oleh karena itu Kemendikbud sudah mengatur bahwa pembelajaran yang dianggap cocok adalah yang mempunyai konsep pendekatan scientific (Nurdin, 2015, hlm. 3). Untuk itu, model pembelajaran yang digunakan adalah Discovery Learning.

Ketertarikan peneliti menggunakan model Discovery Learning untuk meningkatkan representasi matematis siswa bukan tanpa alasan, karena dalam pembelajaran tersebut siswa harus merumuskan kesimpulan dalam menggunakan pendekatan, siswa menemukan pola-pola perlu menggambarkan situasi. Discovery learning model memberikan kesempatan kepada siswa untuk menyingkap atau mencari tahu tentang suatu permasalahan atau sesuatu yang sebenarnya ada namun belum mengemuka dan menemukan solusinya berdasarkan hasil pengolahan informasi yang dicari dan dikumpulkannya sendiri (Kemendikbud, 2017, hlm. 11).

Keterkaitan antara tahap discovery learning dengan representasi matematis yaitu pada tahap pemberian rangsangan, siswa biasanya diberikan sebuah gambar lalu diteliti, setelah itu siswa harus mengidentifikasi masalahnya, dari gambar tersebut siswa mengumpulkan data, lalu dapat diolah datanya menggunakan representasi lain misalnya dalam bentuk tabel atau grafik, setelah itu siswa membuktikan jawaban benar dengan cara presentasi di depan kelas, tahapan akhir siswa dapat menarik kesimpulan dengan menulis interpretasinya.

Discovery learning model dapat meningkatkan kemampuan representasi matematis siswa, hal ini sesuai dengan hasil riset yang dilakukan oleh Heni Yusnani (2015, hlm. 2) terhadap SMP Negeri 13 Bandar Lampung pada materi fungsi kuadrat. Pada penelitian ini mencoba menerapkan discovery learning model pada materi persamaan kuadrat untuk meningkatkan representasi.

Berdasarkan uraian yang telah dipaparkan, peneliti menduga bahwa pembelajaran dengan menggunakan model discovery learning diharapkan mampu meningkatkan representasi matematis siswa. Oleh karena itu, peneliti perlu melakukan sebuah penelitian tindakan kelas dengan judul "Peningkatan Kemampuan Representasi Matematis Siswa Kelas IX-G SMP Negeri 2 
Edisi XIX Volume 1, Januari - Juni 2019

Jurnal Penelitian dan Karya Ilmiah

\section{Bandung pada Materi Persamaan Kuadrat dengan Discovery Learning Model".}

Berdasarkan identifikasi masalah di atas, maka dapat dirumuskan masalah sebagai berikut: 1) Bagaimana peningkatan kemampuan representasi matematis siswa kelas IX-G SMP Negeri 2 Bandung dengan menggunakan discovery learning model? 2) Bagaimana respon siswa terhadap pembelajaran matematika dengan menggunakan discovery learning model dalam meningkatkan kemampuan representasi matematis? 3) Bagaimana efektivitas pelaksanaan pembelajaran matematika dengan menggunakan discovery learning model?

Berdasarkan latar belakang, maka tujuan yang hendak dicapai dari penelitian ini adalah: 1) Mengetahui peningkatan kemampuan representasi matematis siswa dengan discovery learning model pada kelas IX-G SMP Negeri 2 Bandung. 2) Mendeskripsikan respon siswa kelas IX-G SMP Negeri 2 Bandung terhadap pelaksanaan pembelajaran menggunakan discovery learning model. 3) Menganalisis efektivitas pelaksanaan pembelajaran matematika dengan menggunakan discovery learning model dalam meningkatkan kemampuan representasi matematis.

\section{B. METODE PENELITIAN}

Tujuan dalam penelitian ini adalah mengetahui dampak dari penggunaan discovery learning model pada materi persamaan kuadrat terhadap representasi matematis siswa kelas IX, dengan demikian desain penelitian ini berbentuk Penelitian Tindakan Kelas (PTK). Sebagaimana PTK menjadi sebuah implikasi logis dari tujuan dalam penelitian dengan melakukan penelitian di tempat tertentu untuk memecahkan masalah. Hopkins (Wiraatmaja, 2006, hlm. 11) menyatakan penelitian tindakan kelas adalah penelitian yang mengkombinasikan prosedur penelitian dengan tindakan substantif, suatu tindakan yang dilakukan dalam disiplin inkuiri, atau usaha seseorang untuk memahami apa yang terjadi, sambil terlibat dalam sebuah proses perbaikan dan perubahan.

PTK digambarkan sebagai proses dinamis dimana keeempat aspeknya bukan sebagai langkah statis, tetapi lebih merupakan momen dalam bentuk spiral yang menyangkut perencanaan, tindakan, pengamatan, dan refleksi. PTK sebagai suatu rangkaian siklus yang berkelanjutan hingga indikator keberhasilan terpenuhi

Subjek dalam penelitian ini adalah siswa kelas IX-G SMP Negeri 2 Bandung tahun pelajaran 2018/2019. Sedangkan objek yang diteliti dalam penelitian ini adalah kemampuan representasi matematis siswa dan sikap siswa terhadap pembelajaran matematika sdengan menggunakan Discovery learning model. Penelitian ini dilaksanakan secara kolaboratif antara peneliti dan praktisi dalam hal ini guru matematika kelas IX-G SMP Negeri 2 Bandung. Kolaborasi yang dimaksud adalah dalam bentuk kerja sama antara peneliti dan praktisi sehingga memungkinkan terjadi pemahaman dan kesepakatan terhadap masalah yang dihadapi dan pengambilan keputusan yang demokraatis serta menghasilkan kesamaan persepsi terhadap tindakan yang dilakukan.

41 Pelita - Jurnal Penelitian dan Karya Ilmiah 
Teknik pengumpulan data berupa Teknik analisis data Daya Serap Kelas (DSK), observasi, dan angket. Instrumen pengumpulan data berupa lembar tes tertulis, lembar observasi dan angket respon siswa. Meghitung daya serap kelas dengan menggunakan rumus sebagai berikut:

$$
\text { Daya serapKelas }(\%)=\frac{\text { jumlah siswa yang tuntas }}{\text { jumlah siswa keseluruhan }} \times 100 \%
$$

Klasifikasi DSK digunakan skala dari Suherman (2003, hlm. 210) yang penulis sajikan dalam Tabel 1.

\section{Tabel 1}

Kriteria Daya Serap Kelas

\begin{tabular}{cc}
\hline Persentase $\operatorname{DSK}(\%)$ & Kategori \\
\hline $90 \leq D S K \leq 100$ & Sangat Baik \\
$75 \leq D S K<90$ & Baik \\
$55 \leq D S K<75$ & Sedang \\
$40 \leq D S K<55$ & Kurang \\
$D S K<40$ & Buruk \\
\hline Sumber: Suherman (2003, hlm.210)
\end{tabular}

Untuk menghitung nilai rata-rata total dari angket respon siswa, dengan rumus:

$$
X=\frac{\text { total skor siswa }}{\text { banyaknya responden } \times \text { banyak butir }}
$$

Dalam penelitian ini, skor maksimal ideal adalah 4 dan skor minimal ideal adalah 1. Pedoman pengubahan rata-rata skor tiap aspek menjadi data kualitatif dapat dilihat pada Tabel 2 berikut ini.

Tabel 2. Pedoman Kriteria Rata-Rata Skor Tiap Aspek

\begin{tabular}{cc}
\hline Rata-Rata Skor & Kriteria \\
\hline$X>3,5$ & Sangat Baik \\
$3,0<X \leq 3,5$ & Baik \\
$2,0<X \leq 3,0$ & Cukup \\
$1,0 \leq X \leq 2,0$ & Kurang \\
\hline
\end{tabular}

Sumber: Kuntiaraningrat (dalam Septiana, 2016, hlm. 29)

Data hasil observasi kegiatan guru dan siswa, dianalisis dengan menggunakan rumus persentase yaitu: 


$$
\text { Persentase }(P)=\frac{\text { jumlah skor }}{\text { bnyk aspek yang diamati }+ \text { bnyk pengamat }} \times 100 \%
$$

Kriteria P dapat dilihat pada tabel berikut.

Tabel 3. Kriteria Aktivitas Guru dan Siswa

\begin{tabular}{cc}
\hline Persentase & Kriteria \\
\hline$p \geq 90 \%$ & Sangat Baik \\
$80 \% \leq p \leq 89 \%$ & Baik \\
$70 \% \leq p \leq 79 \%$ & Cukup \\
$60 \% \leq p \leq 69 \%$ & Kurang \\
$p \leq 50 \%$ & Sangat Kurang \\
\hline Sumber: Nana Sudjana $(1999$, hlm. 118)
\end{tabular}

\section{HASIL PENELITIAN DAN PEMBAHASAN}

Penelitian tindakan kelas ini telah dilaksanakan di SMP Negeri 2 Bandung mulai tanggal 27 Agustus 2018 sampai 23 September 2018. Dalam kegiatan penelitian tindakan kelas ini, peneliti bertindak sebagai guru dalam melaksanakan proses pembelajaran. Proses pembelajaran yang dilaksanakan pada siklus I, dan siklus II dengan discovery learning model, sedangkan untuk observer sebanyak 2 orang yaitu observer 1 dan observer 2. Penelitian tindakan kelas ini dilaksanakan sebanyak dua siklus dari tiga siklus yg rencanakan. Siklus I dilaksanakan dalam tiga kali pertemuan, dengan rincian pertemuan pertama dan kedua adalah kegiatan pembelajaran, sedangkan pertemuan ketiga adalah untuk tes akhir siklus.

Pelaksanaan pembelajaran pada setiap pertemuan dilaksanakan dengan menggunakan discovery learning model dalam pembelajaran

Setiap kali kegiatan pembelajaran, siswa dibentuk menjadi beberapa kelompok kecil. Siswa diberikan situasi mengenai materi persamaan kuadrat, siswa diharapkan menemukan solusi untuk menyelesaikan pertanyaan yang tersedia. Observer melakukan pengamatan sesuai dengan lembar observasi yang telah disediakan.

Hasil penelitian tindakan kelas yang terdiri dari siklus I dan siklus II ketika pembelajaran matematika dengan discovery learning model menunjukkan adanya peningkatan representasi matematka siswa dalam pembelajaran matematika. Hal ini terlihat dari analisis data representasi matematika siswa dalam pembelajaran matematika pada siklus I dan siklus II yang mengalami peningkatan.

Analisis tes kemampuan representasi dilihat dari Daya Serap Kelas yang disajikan pada Tabel 4 . 
Jurnal Penelitian dan Karya Ilmiah

\section{Tabel 4. Analisis Daya Serap Kelas Antar Siklus}

\begin{tabular}{|c|c|c|c|}
\hline Siklus & $\begin{array}{c}\text { Persentase } \\
\text { Ketuntasan }\end{array}$ & Kriteria & Perubahan \\
\hline I & $31,25 \%$ & Buruk & \multirow{2}{*}{$56,25 \%$} \\
\hline II & $87,5 \%$ & Baik & \\
\hline
\end{tabular}

Berdasarkan Tabel 4, terlihat bahwa persentase Daya Serap Kelas meningkat sebesar 56,25\% dari siklus I ke siklus II dengan persentase DSK pada siklus II mencapai $87,5 \%$ berada pada kriteria Baik. Peningkatan DSK tersebut sudah sesuai dengan kriteria ketuntasan kemampuan repserentasi matematis siswa yang ditetapkan oleh peneliti. Oleh karena itu, penelitian ini diberhentikan.

Respon siswa terhadap pembelajaran matematika menggunakan model discovery learning dalam penelitian ini diperoleh dari hasil analisis pada angket respon siswa. Angket respon diberikan pada pertemuan terakhir siklus. Tabel 4.9 berikut merupakan hasil analisis angket respon siswa secara keseluruhan.

Berdasarkan Tabel 5 dapat diketahui bahwa respon yang diberikan siswa terhadap pembelajaran matematika menggunakan model discovery learning memenuhi kriteria minimal baik pada semua aspek. Secara keseluruhan respon siswa terhadap pembelajaran matematika menggunakan model discovery learning memiliki kriteria Baik dengan skor rata-rata 3,17.

Tabel 5. Hasil Analisis Angket Respon Siswa

\begin{tabular}{lccc}
\hline \multicolumn{1}{c}{ Aspek Penilaian } & $\begin{array}{c}\text { Jumlah } \\
\text { Skor }\end{array}$ & $\begin{array}{c}\text { Rata-rata } \\
\text { Skor }\end{array}$ & Kriteria \\
\hline $\begin{array}{l}\text { Sikap siswa terhadap } \\
\text { pembelajaran }\end{array}$ & 312 & 3,25 & Baik \\
$\begin{array}{l}\text { Minat siswa terhadap } \\
\text { pembelajaran }\end{array}$ & 402 & 3,14 & Baik \\
$\begin{array}{l}\text { Keuletan siswa dalam } \\
\text { memahami masalah }\end{array}$ & 308 & 3,21 & Baik \\
\hline \multicolumn{1}{c}{ Total } & $\mathbf{1 0 1 5}$ & $\mathbf{3 , 1 7}$ & Baik \\
\hline
\end{tabular}

Hasil observasi secara keseluruhan terhadap akivitas guru dengan menggunakan discovery learning model dapat dilihat pada tabel berikut. 
Edisi XIX Volume 1, Januari - Juni 2019

Jurnal Penelitian dan Karya Ilmiah

Tabel 6. Hasil Observasi Aktivitas Guru

\begin{tabular}{ccc}
\hline \multirow{2}{*}{ Siklus ke- } & \multicolumn{2}{c}{ Observasi Aktivitas Guru } \\
\cline { 2 - 3 } & Persentase & Kriteria \\
\hline 1 & $83,65 \%$ & Baik \\
2 & $92,31 \%$ & Sangat Baik \\
\hline Rata-rata & $87,98 \%$ & Baik \\
\hline
\end{tabular}

Berdasarkan hasil pada tabel 6 di atas, aktivitas pembelajaran yang dilakukan guru dinyatakan dengan persentase $\mathbf{8 7 , 9 8 \% , ~ d a p a t ~ d i s i m p u l k a n ~ b a h w a ~}$ pelaksanaan pembelajaran telah sesuai dan berjalan dengan Baik.

Secara umum hasil observasi terhadap aktivitas siswa dengan menggunakan discovery learning model dapat dilihat pada tabel berikut.

Tabel 7. Hasil Observasi Aktivitas Siswa

\begin{tabular}{ccc}
\hline \multirow{2}{*}{ Pertemuan ke- } & \multicolumn{2}{c}{ Observasi Aktivitas Siswa } \\
\cline { 2 - 3 } & Persentase & Kriteria \\
\hline 1 & $83,82 \%$ & Baik \\
2 & $91,18 \%$ & Sangat Baik \\
\hline Rata-rata & $87.5 \%$ & Sangat Baik \\
\hline
\end{tabular}

Berdasarkan Tabel 7, aktivitas pembelajaran yang dilakukan siswa memperoleh persentase 87,5\% dengan kriteria "Baik".

\section{KESIMPULAN}

Berdasarkan hasil analisis data dan pembahasan hasil penelitian, diperoleh kesimpulan sebagai berikut: 1) Pembelajaran matematika dengan discovery learning model terdapat peningkatan kemampuan representasi matematis siswa kelas IX-G di SMP Negeri 2 Bandung. Namun terdapat perbedaan kriteria antar siklusnya. 2) Respon siswa terhadap pembelajaran matematika menggunakan discovery learning model memiliki kriteria baik. 3) Rata-rata persentase aktivitas guru siklus I berada pada kriteria baik dan meningkat pada siklus II dengan kriteria sangat baik. Rata-rata persentase aktivitas siswa siklus I berada pada kriteria baik dan meningkat pada siklus II dengan kriteria sangat baik. 
PENINGKATAN KEMAMPUAN REPRESENTASI MATEMATIS SISWA

KELAS IX-G SMP NEGERI 2 BANDUNG PADA MATERI

PERSAMAAN KUADRAT DENGAN DISCOVERY LEARNING MODEL

Siti Tuti Alawiyah, \& Jarnawi Afgani Dahlan

\section{Referensi}

Arikunto, S. (2009). Dasar-dasar evaluasi pendidikan edisi revisi. Jakarta: Bumi Aksara. (2009). Manajemen Penelitian. Jakarta: Rineka Cipta.

Hamdani, dkk. (2015). Kemampuan representasi matematis siswa ditinjau dari gaya belajar pada materi fungsi kuadrat di SMA. Jurnal matematika atau pembelajarnnya. Pontianak: Universitas Tanjungpura.

Hopkins, D. (2011). Panduan guru penelitian tindakan kelas/ a teacher's guide to classroom research. Yogyakarta: Pustaka Belajar.

Kartini. (2009). Peranan dalam pembelajaran matematika.[Online]. Diakses dari: http://eprints.uny.ac.id/7036/1/P22-Kartini.pdf. (01 Juni 2018).

Kemendikbud. (2017). Model-model pembelajaran. Jakarta: Kemendikbud.

Mudzakir. (2006). Representasi belajar berbasis masalah. Jurnal matematika atau pembelajarannya. ISSN: 085-7792.

NCTM. (2000). Principles and standards for school mathematics. Reston, VA: NCTM.

Nurdin, M. (2015). Pengaruh metode discovery learning untuk meningkatkan representasi matematis dan percaya diri siswa. Garut: Universitas Garut.

Sudjana, N. (1999). Penilaian hasil proses belajar mengajar. Bandung: Remaja Rosdakarya.

Sudjana. (2005). Metode Statistika. Bandung: Tarsito.

Sugiyona. (2012). Metode penelitian pendidikan (pendekatan kuantitatif, kualitatif, dan $r \& d)$. Bandung: Alfabeta.

Suherman, E. (2003). Petunjuk Praktis untuk Melaksanakan Evaluasi Pendidikan Matematika. Bandung: Wijayakusuma.

Surahmi, E. (2015). Representasi siswa SMA dalam memahami konsep fungsi kuadrat ditinjau dari gaya kognitif. Jurnal matematika atau pembelajarannya. Pamekasan: Universitas Madura.

Wijaya, A. (2012). Pendidikan matematika realistik: suatu alternatif pendekatan pembelajaran matematika. Yogyakarta: Graha Ilmu.

Wiriatmaja, R. (2016). Metode penelitian tindakan kelas. Bandung: PT. Remaja Rosdakarya.

Yusnani, H. (2016). Penerapan model discovery learning terhadap kemampuan representasi matematis dan self efficacy siswa. Bandar Lampung: Universitas Lampung. 